\title{
Increase in The Use of Organic Fertilizers as Complements to Inorganic Fertilizers in Maintenance of Soil Fertility and Environmental Sustainability
}

\author{
Joseph Xorse Kugbe*, Wuni Mawiya, Alhassan Mohammed Hafiz and Charles Maganoba \\ Department of Agronomy, University for Development Studies, Tamale, Ghana
}

*Corresponding author: Joseph Xorse Kugbe, Department of Agronomy, University for Development Studies, Tamale, Ghana.

Received Date: December 02, 2019

Published Date: December 11, 2019

\begin{abstract}
Soil fertility can be considered in different ways, depending on land use. In intensively managed cropping systems, soil fertility can be defined in terms of the temporal value of products produced relative to inputs used, including the economic aspects of nutrient budgeting. For environmentally sustainable soil productivity, an integral use of both organic and inorganic fertilizer to ensure adequate supply of plant nutrients and sustain maximum crop yield and profitability is advocated. However, inorganic fertilizer is expensive and largely unaffordable to the resource-poor farmers found mostly across sub sahara Africa. Being readily available as a cheap source of nutrients, organic inputs, including poultry manure should complement inorganic fertilizers. Organic fertilizers supply the essential macro- and micro-nutrient elements to plants, as well as improve soil physico-chemical conditions for better crop growth and yield.
\end{abstract}

Keywords: Integrated soil fertility management; Crop production; Organic fertilizer; Inorganic fertilizer

\section{Introduction}

Soil is taken for granted by most farmers, who often think of it as an inert support for plants. In reality, it is a dynamic, living resource whose condition is vital for food production and for the function of the ecosystem as a whole. The fertility of soil can be considered in different ways, depending on land use. In intensively managed agricultural and horticultural systems, and even in forestry, soil fertility can be defined in terms of the value of products produced relevant to inputs used (including economic aspects of nutrient budgeting). Alternatively, the emphasis may be on quality or productivity.

Soil fertility maintenance is a major concern in tropical Africa [1], particularly with the rapid population increase, which has occurred in the past few decades. In traditional farming systems, farmers use bush fallow, plant residues, household refuse, animal manures and other organic nutrient sources to maintain soil fertility, organic matter and general soil productivity. Although this reliance on biological nutrient sources for soil fertility regeneration is adequate for cropping systems with low cropping intensities, it becomes unsustainable with more intensive cropping unless fertilizers are applied [2].
Thus, the concept of soil fertility and the choice of fertility management is specific to a given context. However, in all contexts, soil fertility depends on physical, chemical and biological characteristics [3]. When soil fertility is considered in terms of the highest practical level of productivity, the focus is mostly on physical and chemical aspects of the soil. It is important to note that some aspects of the biological component of soil fertility can be overridden by addition of fertilizers, but this is not a simple phenomenon, because increase in plant growth that is associated with addition of fertilizers can increase other aspects of the biological activity in soil [4].

In a sustainable agricultural or horticultural system, soil fertility can be considered in terms of the amount of input relative to the amount of output over a long period, using a budgeting approach [2]. This definition is different from the one that defines fertility in relation to a maximum level of productivity in the short-term or at a given point in time [5]. A definition that focuses on shortterm productivity is based on the capacity of soil to immediately provide plant nutrients [6]. When sustainability of the soil resource is emphasized in the context of soil fertility, biological components 
may become more relevant because of its long-term impact on productivity that has been variously reported [7]. A change in focus from the highest practical level of productivity to a lower, profitable and persistent level of production; temporally depend on soil biological processes. In that sense, the physical, chemical and biological components of soil are essential for sustained soil productivity.

\section{Environmental Sustainability Essential for Today's Soil Productivity}

Sustainable agriculture refers to a farming system that seeks to achieve maximum productivity of crops and livestock that will satisfy human needs for food and fibre whiles maintaining the integrity of the ecology. A productive soil needs to be looked after. There is the need to make the most efficient use of all non-renewable resources in the soil to sustain economic viability and enhance the quality of life [8]. Sustainable agriculture adopts a holistic approach with an ultimate goal of achieving continuity in health of the soil and the people to which the system affects [9]. In that sense, all systems, processes and interactions that eventually impact the soil health must be identified for a given geographic location before long lasting impacts due to soil usage are implemented. Often, and most especially across resource-poor zones like sub Saharan Africa, knowledge of such location-specific soil interactions and processes are limited in practice. The knowledge limitation hinders the efficient and sustainable usage of soil resources for the benefit of the environment, and for the production of food for the everincreasing human population [10].

\section{Declining Soil Fertility in the Guinea Savanna Zone of Africa Should be a Call for Concern}

Over the years, enhancing and maintaining the fertility of soils across the Guinea savanna zone of Africa have become very critical issues that need to be addressed to meet the food security of these developing countries [1]. Soil fertility has been impaired by continuous cropping; with low inputs of mineral nutrients. This has been identified as a major threat, not only to food production but also to ecosystem viability [11]. Generally, improving the nutritional status of plants through the application of mineral fertilizers, and the persistence maintenance of soil health and fertility has resulted into the production of double the quantity of food produced in both developed and developing countries since the beginning of the 'Green Revolution' [12]. Across the Guinea Savanna zone, increases in cereal production in the past 40 years are associated with corresponding increases in fertilizer consumption [13].

According to Tillman [11] the doubling of food production during the past 40 years has been associated with about 6.9-fold increases in $\mathrm{N}$ fertilization, 3.5-fold increase in P fertilization and only 1.1-fold increase in cultivated land area. Similar observations have been reported in Asia [14]. As human population continues to increase however, this increase in fertilizer consumption is not enough to sustain food security and would have to be increased to over $250 \mathrm{~kg}$ ha-1 of NPK [12,14].
Nearly all increases in projected food requirements in the next decades will be the result of enhancements in yield per unit area and intensive use of agricultural land [2]. To increase yield capacity of crop plants and to ensure global food demand in 2020, fertilizer use should increase from 144 million tons in 1990 to 208 million tons in $2020[13,15]$. Possibly, this projected increase in fertilizer consumption by 2020 will not be adequate to meet both food production requirements and nutrient depletions that are due to nutrient removal by harvesting crops from soils. This portion of the un-estimated nutrient depletion should be of grave concern to soil scientists, as the value of its estimate can help predict the temporal health of a given soil. Byrnes and Bumb [16] estimate that by 2020 , global fertilizer consumption should increase up to 300 million tons to match required demands for food production and nutrient removal from soils. In view of this estimates, there is the need for countries in the Guinea savanna zone of Africa to develop and adopt fertilizer accessible policies and take new measures to provide more support to the resource-poor farmers regarding the supply of fertilizers.

\section{Major Challenges Facing Soil Fertility and Environmental Sustainability}

Inadequate use of fertilizers raises concerns due to its adverse effects on the environment. The eutrophication of surface waters, pollution of drinking waters and fertilizer-associated greenhouse gaseous emissions that causes global warming are some environmental concerns [17-19]. There is a very close relationship between application rates of $\mathrm{N}$ fertilizers and the emission of nitrous oxide (N2O) [20]. Nitrous oxide is one of the most important greenhouse gases that impacts the global climate [17]. About 0.5-1.5 of fertilizer $\mathrm{N}$ applied is lost from soil as gaseous emissions $[18,19]$. Several management strategies have been developed to control and minimize $\mathrm{N}$ losses. These include use of $\mathrm{N}$ fertilizers with enzyme inhibitors like urease and nitrification inhibitors, controlled-release $\mathrm{N}$ fertilizers, accurate timing and placement of fertilizers, and soil and plant analysis to define rates of $\mathrm{N}$ application [21-23].

In these senses, nutrient use efficiency and improved soil management has become an important challenge, particularly for $\mathrm{N}$ and $\mathrm{P}$ fertilizers [23]. When the application of $\mathrm{N}$ fertilizers is not properly managed and is realized at excessive levels, losses of $\mathrm{N}$ from agricultural lands can occur through the leaching of NO3, volatilization of $\mathrm{NH} 3$ or emission of $\mathrm{N}$ oxides $[17,20]$. The leaching and runoff of NO3 into ground water and surface waters is a major environmental problem in developed countries, particularly in Europe [24]. It is gaining increasing attention in fast growing economies like China and should be avoided at all cost in Africa. Pollution of ground water with NO3 impairs the quality of drinking water and causes various harmful effects on human health [25]. Contamination of lakes and rivers with NO3 stimulates algal growth and depletion of respiration-required oxygen, resulting in an increasing risk of fish deaths on a large scale [25,26]. Adequate knowledge and use of both organic and inorganic sources of fertilizers, in terms of time of application, rate of application, 
method of application, and storage aid to reduce the impact of fertilizer application and losses on the environment.

\section{Combined use of Organic and Inorganic Fertilizers Essential for Sustained Soil Productivity}

Several studies have shown that the application of fertilizers, both from organic and inorganic sources significantly improves the growth and yield of most crops $[27,28]$. Thus, an integral use of both organic and inorganic fertilizer to ensure adequate supply of plant nutrients and sustain maximum crop yield and profitability has been advocated [4]. However, inorganic fertilizer is expensive and may be largely unaffordable, hence not readily available to resource-poor farmers across sub-Saharan Africa. Some findings show that the intensive continuous application of inorganic fertilizers, solely, cannot sustain the high yield of vegetable production [28]. On the other hand, organic manure such as poultry droppings is comparatively available as a cheap source of nutrients for sustainable crop production [15]. Besides the supply of essential macro and micro nutrient elements to plants, organic fertilizers improve soil physico-chemical conditions, enhance soil productivity, increase the soil organic carbon content, soil flora and fauna, soil crumb structure and the nutrient status of the soil towards attaining sustainably high yields [27].

Organic inputs contain nutrients that are released at a rate determined in part by their chemical characteristics or organic resource quality. For this reason, organic inputs applied at realistic levels seldom release sufficient nutrients for acceptable crop yield.

It has been suggested that methods involved in the current agricultural production should rather be geared towards strategies that are compatible with the principles of sustainable intensification under the agricultural production systems [14] and which are promising to the fulfilment of the needs of the present and posterity. These are the ones that involve the mobilization and use of all nutrient resources that are available to the farmer.

Combine use of organic and mineral inputs has been advocated for smallholder farming in the tropics because neither input is usually available in sufficient quantities to maximize yields and also because both are needed in the long-term to sustain soil fertility and crop production. An important question arises within the context of integrated soil fertility management: Can organic resources be used to rehabilitate less-responsive soils and make these responsive to fertilizer? In Zimbabwe, applying farmyard manure to sandy soils at relatively high rates for 3 years resulted in a clear response to fertilizer where there was no such response before rehabilitation [29].

\section{Conclusion}

An integral use of both organic and inorganic fertilizer to ensure adequate supply of plant nutrients and sustain maximum crop yield and profitability is advocated. However, inorganic fertilizer is expensive and may be largely unaffordable and not available to the resource-poor farmers found mostly across sub sahara Africa. On the other hand, organic manure, such as poultry droppings is readily available as a cheap source of nutrients for sustainable crop production. Organic fertilizer supplies the essential macro- and micro-nutrient elements to plants, as well as improves soil physicochemical conditions for better crop growth and yield.

\section{Acknowledgement}

None.

\section{Conflict of Interest}

No conflict of interest.

\section{References}

1. Yasuhiro T, Tovohery R, Atsuko, T Kazuki S (2019) Challenges and opportunities for improving $\mathrm{N}$ use efficiency for rice production in subSaharan Africa. Plant Production Science.

2. Oldfield E, Bradford MA, Wood SA (2019) Global meta-analysis of the relationship between soil organic matter and crop yields. Soils 5: 15-32.

3. Walsh E, Mc Donnell KP (2012) The influence of added organic matter on soil physical, chemical, and biological properties: a small-scale and short-time experiment using straw. Archives of Agronomy and Soil Science 58(1): S201-S205.

4. Bargaz A, Lyamlouli K, Chtouki M, Zeroual Y, Dhiba D, et al. (2018) Soil Microbial Resources for Improving Fertilizers Efficiency in an Integrated Plant Nutrient Management System. Frontiers in Microbiology 9: 1606.

5. De Bruyna AH, Halloran IPO, Lauzon JD, Van Eerd LL (2019) Nitrogen and phosphorous fertilizer timing, source, and placement in sugarbeet. Agronomy Journal 111(2): 859-866.

6. Barbosa ERM, Tomlinson KW, Carvalheiro LG, Kirkman K, De Bie S, et al. (2014) Short-Term effect of nutrient availability and rainfall distribution on biomass production and leaf nutrient content of savanna tree species. PLOS ONE 9(3): e92619.

7. Lima CEP, Fontenelle MR, Borba Silva LR, Soares DC, Moita AW, et al. (2015) Short-term changes in fertility attributes and soil organic matter caused by the addition of EM Bokashis in Two Tropical Soils. International Journal of Agronomy.

8. Farm Bill USDA (1990) Food, Agriculture, Conservation, and Trade Act of 1990, Public Law 101-624. Title XVI, Subtitle A, Section 1603. Washington, DC: US Government.

9. Idowu EO (2013) The role of climate, soil and crop on sustainable Agriculture in Nigerian ecological zones: A Brief Overview. Scintia Agriculture 4(1): 26-36.

10. Sayed RM, Hamdollah E (2011) A General Overview on Intercropping and its Advantages in Sustainable Agriculture. Journal of Applied Environmental and Biological Sciences 1(2): 482-486.

11. Tillman D (1999) Global environmental impacts of agricultural expansion: the need for sustainable and efficient practices. Proceeding of National Academy of Science USA 96: 5995-6000.

12. Loneragen JP (1997) Plant nutrition in 20th and perspectives for the21st century. Plant Soil 196: 163-174.

13. FAO (2000) Fertilizer requirements in 2015 and 2030. FAO, Rome.

14. Hossain M, Singh VP (2000) Fertilizer use in Asian agriculture: implications for sustaining food security and the environment. Nutrient Cycling in Agroecosystems, 57: 155-169.

15. Bumb BL, Baanante CA (1996) The role of fertilizer in sustaining food security and protecting the environment to 2020,2020 Vision Discussion Paper 17. International Food Policy Research Institute, Washington, DC.

16. Byrnes BH, Bumb BL (1998) Population growth, food production and nutrient requirements. In Journal of Crop Production. Ed. Z Rengel, pp. 1-27, The Haworth Press, New York.

17. Portmann RW, JS Daniel, Ravishankara AR (2012) Stratospheric ozone depletion due to nitrous oxide: influences of other gases. Phylosophycal 
Transaction of the Royal Society B 367: 1256-1264.

18. Smith KA, Mc Taggart IP, Tsuruta H (1997) Emissions of N2Oand NO associated with Nitrogen fertilization in intensive agriculture, and the potential for mitigation. Soil Use Management 13: 296-304.

19. Veldkamp E, Keller M (1997) Fertilizer-induced nitric oxide emissions from agricultural soils. Nutrient Cycling in Agroecosystems 48: 69-77.

20. Erickson H, Keller M, Davidson EA (2001) Nitrogen oxide fluxes and nitrogen cycling during post agricultural succession and forest fertilization in the humid tropics. Ecosystems 4: 67-84.

21. Addai I, Kugbe J (2019) Planting dates and nutrition management regimes impact positively on bulb size, quality and yield of rain-fed onion. Ghana Journal of Science Technology and Development 6(1): 4451.

22. Kugbe JX, Salifu A, Sam EK (2019) Growth and yield of okra (Abelmoschus Esculentus L. Moench) as affected by planting date and weeding regime in northern Ghana. Journal of Agriculture and Crops 5(4): 43-47.

23. Sam EK, Adu Gyamfi R, Kugbe JX (2019) Productive impact of residual nutrients $(\mathrm{N}$ and $\mathrm{P}$ ) in maize and soybean rotation. Asian Journal of Advances in Agricultural Research 10(3): 1-15.
24. Kroeze C, Seitzinger SP (1998) Nitrogen inputs to rivers, estuaries and continental shelves and related nitrous oxide emissions in 1990 and 2050: a global model. Nutrient Cycling in Agroecosystems 52: 195-212.

25. Mosier AR, Bleken MA, Chaiwanakupt P, Ellis EC, Freney JR, et al. (2001) Policy implications of human-accelerated nitrogen cycling. Biogeochemistry 52: 281-320.

26. Maene LM (2000) Efficient fertilizer use and its role in increasing food production and protecting the environment. 6th AFA International Annual Conference, Cairo, Egypt.

27. Agbede TM, Adebayor J (2008) Effects of poultry manure on soil physical and chemical properties, growth and grain yield of sorghum in southwest Nigeria. American European Journal of Sustainable Agriculture 2(1): 7277.

28. Ogundare SK, Babalola TS, Hinmikaiye AS, Oloniruha JA (2015) Growth and fruit yield of tomato as influenced by combined use of organic and inorganic fertilizer in Kabba, Nigeria. European Journal of Agriculture and forestry Research 3(3): 48- 56.

29. Zingore S, HK Murwira RJ Delve, KE Giller KE (2007) Soil type, management history and current resource allocation: Three dimensions regulating variability in crop productivity on African smallhoder farms. Field Crops Research 101: 296-305. 